\title{
Napjainkban alkalmazott kerekes harcjárművek és fejlesztésük az elmúlt évtizedekben tiresz
}

\section{A kerekes harcjármúvek és a szovjet/orosz BTR jármüvek korszerüsítése}

\section{ELőZMÉNYEK}

Az elmúlt évszázadok katonai konfliktusai során állandó és visszatérő probléma volt a katonatömegek mozgatása, illetve szállítása. A technikai, valamint az infrastrukturális fejlődés ezt a feladatot a katonai igények minél nagyobb szintű kielégítésével volt képes megoldani. Az általános katonai elvárást úgy lehet megfogalmazni, miszerint a katonát sértetlenül, és lehetőleg olyan állapotban kell a harc megvívásának helyszínére szállítani, hogy az a fizikai képességeinek a legjobb kihasználásával legyen képes bekapcsolódni a harctevékenységbe.

A szállítási lehetőségek az évszázadok során folyamatosan bővültek. Ezek közé tartozott az állati erő, majd a vasút, de a problémát teljes komplexitásában csak a belsőégésű motor megjelenését követően lehetett megoldani. A vasúti szállítás és a teherautók csapatszállítás célú igénybevétele nagy előrelépést jelentett, de ezek alkalmazásának az infrastruktúra igénye nagy és összetett. További hiányosság, hogy ezen megoldások védettséget nem nyújtottak a katona számára.

A XX. század első felében már megjelentek, de lényegében csak a második felétől terjedtek el azok az eszközök, amelyek:

- védettséget nyújtottak a kézifegyverek tüze ellen;

- olyan mozgékonysággal rendelkeztek, hogy képesek voltak a talajutakról letérve a nyílt terepen is közlekedni;

- fedélzeti fegyverzettel rendelkeztek, amelyekkel képesek voltak korlátozottan tǔztámogatást is biztosítani.
Ezeket az eszközöket gyalogsági harcjárműveknek, illetve lövészpáncélosnak, ha a járószerkezet alapján pontosítjuk az elnevezést, akkor kerekes harcjárműveknek nevezzük. Az ilyen a harceszközök a mozgékonyság, tűzerő, és védettség szempontjait a harcban betöltött szerepük alapján, eltérő szinten teljesítik. Ebből következik, hogy a felsorolt szempontok betöltésének a minőségére vonatkozó elvárások alapján, járószerkezet tekintetében megjelentek a lánctalpas és a kerekes megoldások. A lánctalpas harcjárművek, a lánctalp nagyobb teherbíró képessége miatt vastagabb páncélzattal és nagyobb űrméretű fegyverzettel szerelhetők, míg a kerekes, könnyebb harcjármüvek vékonyabb páncéllal és kisebb tűzerővel rendelkeznek. Az elmúlt két évtizedben a kerekes harcjármúvek alkalmazása sokkal jelentősebb volt. Ennek az okát az alacsonyabb fenntartási költségekben és a kisebb tömeg miatti könnyebb szállíthatóságban lehet keresni (1. táblázat).

\section{A KEREKES HARCJÁRMŰVEK ELTERJEDÉSE}

Az elmúlt évtizedekre jellemző helységharcokban - a szilárd útburkolat miatt - elterjedt a változó terepviszonyok esetén is jól alkalmazható gumikerekes harcjárművek alkalmazása [2]. Problémaként merült fel a lánctalpas eszközökkel szemben az is, hogy az alacsony végsebességük miatt nagy sebességü konvoj, menetoszlop kísérésére alkalmatlannak bizonyultak [3].

A páncélozott kerekes járműveket már a második világháború előtt és alatt is alkalmaztak [4. 35. o.], de az alábbi
ÖSSZEFOGLALÁS: Az elmúlt évtizedek konfliktusai jelentős mértékben befolyásolták a harcjármúvek alkalmazását és ebből adódóan az eszközökre vonatkozó harcászati igényeket. A folyamatosan változó katonai igények a harcjármúvek gyártóinál különböző fejlesztési irányokat indukáltak. A cikksorozat tíz harcjármű fejlesztési vonalát mutatja be. A leírások egy jármútípus több változatát tartalmazzák, az időrendi sorrendet követve. A szerzők olyan fegyveres konfliktusokat is feldolgoznak, amelyekben a vizsgált harcjármüvek szerepet kaptak, illetve amelyekhez az eszközök fejlesztése szorosan köthető́.

KULCSSZAVAK: kerekes harcjármú, védettség, szállítási kapacitás, mozgékonyság, tüzerő
ABSTRACT: The conflicts of the past decades have significantly affected the usage of the combat vehicles and due to this the equipment related tactical demands as well. The continuously changing military demands induced different directions of development for the combat vehicle manufacturers. The article series intruduces the development of ten combat vehicles. The descriptions contain multiple versions of one vehicle type, considering the chronological order. Armed conflicts in which the examined combat vehicles play a role and which are in close connection with the equipment development are included.

KEY WORDS: Wheeled armored vehicle, protection, transport capability, mobility, fire power

\footnotetext{
NKE HHK Haditechnikai Tanszék. ORCID: 0000-0003-0632-5650

* NKE HHK Haditechnikai Tanszék. ORCID: 0000-0001-7594-2383
} 
1. táblázat. A különböző harcjármű típusok erősségei és gyengeségei (Forrás [1])

\begin{tabular}{|c|c|c|c|c|}
\hline Harcjármú-tulajdonság & $\begin{array}{c}\text { Könnyen páncélozott } \\
4 \times 4 \text { hajtásképletű } \\
\text { jármú }\end{array}$ & $\begin{array}{c}\text { Kerekes } \\
8 \times 8 \text { hajtásképletú } \\
\text { harcjármú }\end{array}$ & $\begin{array}{l}\text { Lánctalpas } \\
\text { harcjármú }\end{array}$ & Harckocsi \\
\hline hadműveleti mozgékonyság & 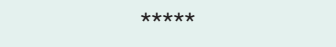 & 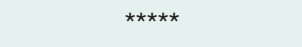 & 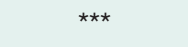 & * \\
\hline harcászati mozgékonyság & ** & 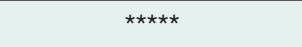 & **** & $\star \star \star \star ~$ \\
\hline terepjáró képesség & ** & 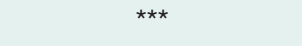 & 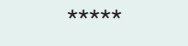 & 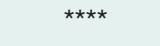 \\
\hline védettség & ** & *** & 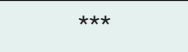 & 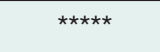 \\
\hline tűzerő & * & 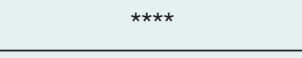 & 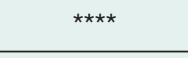 & 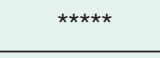 \\
\hline megbízhatóság & 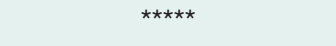 & 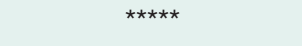 & 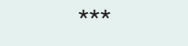 & ** \\
\hline költség & 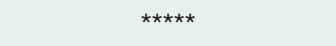 & 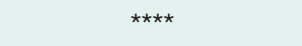 & ** & * \\
\hline
\end{tabular}

gyengeség ${ }^{*}$ erősség $=^{\star \star \star \star \star \star ~}$
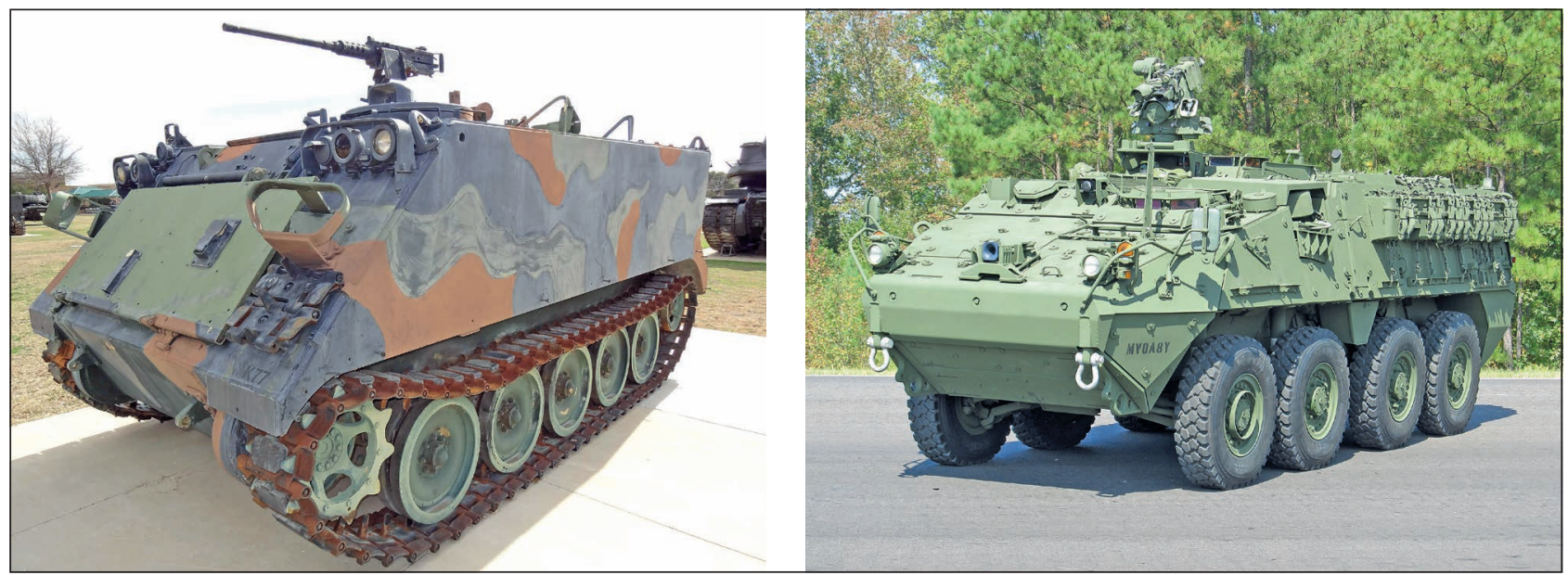

1. ábra. Az M113 (bal oldali kép) és a Stryker DVH harcjármúvek [9], [10]

példák alapján kijelenthető, hogy a mai európai vagy szovjet eredetű típusok előzményei az 1960-as, '70-es évekig nyúlnak vissza:

- A BTR-80 harcjármű előd típusa, a BTR-60, 1960-ban jelent meg [5].

- A Bundeswehr által alkalmazott Fuchs járművek tervei először a '60-as években készültek el [6, 441-445. o.], [4, 136. o.].

- A Piranha jármúcsalád gyártása a '70-es években indult el $[7,30$. o.].

- A francia hadsereg által alkalmazott VAB járművek fejlesztése 1974-ben kezdődött meg [8].

A II. világháború után az Amerikai Egyesült Államok hadereje gyors ütemben igyekezett csökkenteni a kerekes jármúveinek számát, de az 1990-es évek második felében egy teljesen ellentétes folyamat indult meg a kerekes harcjárművek térnyerésével. A 2000-es évek elejére megkezdték az addig alkalmazott M113 lánctalpas csapatszállító eszközök lecserélését kerekes harcjárművek$\mathrm{re}^{1}[11,87.0$.

A délszláv konfliktusban szerzett tapasztalatok egyike, hogy a térség hegyes területein a téli időszakban lánctalpas technikára jellemző alacsonyabb talajnyomás a jeges lejtőkön, egyértelmű hátrányt jelentett a csapatszállítási feladatokban [12].

A stratégiai mozgékonyság, azon belül a légi úton szálíthatóság a 2000-es évek elején vált fontossá. Ebben a tekintetben a kerekes harcjárművek - néhány kivételtől eltekintve - szintén előnybe kerültek a lánctalpas eszközökhöz képest:

2. ábra. A BMP-1-es és a BTR-80-as harcjárművek [17]

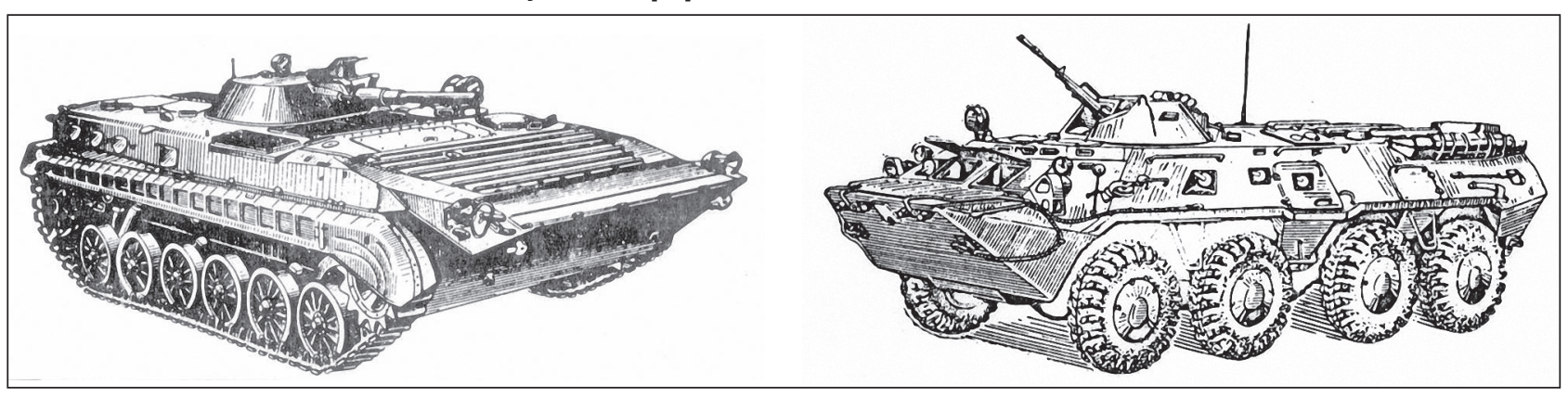


- kisebb, 17 t alatti tömeg üres állapotban;

- gyorsabban képes elhagyni a repülőgépet és onnan távolabb, a kijelölt helyen megállni, azaz lerövidül a kirakodás időszükséglete.

Példaként említhető, hogy a C-130-as repülőgéppel, légi utántöltés nélkül 1800 km-re egy Stryker ICV járművet is el lehetett szállítani [13, 68-69. o.].

Az Amerikai Egyesült Államokban az IAV (Interim Armored Vehicle), azaz átmeneti páncélozott jármű program [14] keretében hat SBCT-t (Stryker Brigade Combat Team), azaz Stryker dandár harccsoportot szereltek fel kerekes eszközökkel a kétezres évek elejétől kezdve. A kerekes eszközök terjedésére igen jó példa, hogy Lengyelország 2002-től egy 10 éves beszerzési program keretein belül 690 db Patria járművet állított rendszerbe Rosomak néven [15 o. 18]. Ennek a folyamatnak a magyar vonatkozása, hogy a Magyar Honvédségben kivonták a BMP-1 típusú lánctalpas eszközöket, amelyek csapatszállító szerepét a BTR-80 és BTR-80A típusok vették át.

\section{A KEREKES HARCJÁRMÜVEK FELADATAI ÉS ELNEVEZÉSEI}

A világ hadiipara az elmúlt évtizedekben nagyon sok típust gyártott páncélozott csapatszállító járművekből, azon belül kerekes harcjárművekből, illetve átalakította és modernizálta azokat. Több típus, illetve azok altípusai, módosított és modernizált változatai más elnevezéssel és más kiegészítő jelzésekkel, több nemzet haderejében is a mai napig alkalmazásban vannak. ${ }^{2}$ A cikksorozatban bemutatott járművek körében nagyon sok eszköz a rendeltetésére utaló elnevezést kapott, és mind a magyar nyelvű, mind a külföldi nevek szó szerinti vagy tartalmi fordításai jelentésbeli különbségeket mutatnak. Az idegen nyelvű irodalmak által tárgyalt elnevezések sok esetben keverednek, vagy idővel megváltoznak, illetve az elmúlt két évtizedben a rövidítések, elnevezések száma jelentősen megnőtt.

A fellelhető kifejezések nagy száma arra utal, hogy többféle elnevezési csoport létezik, amelyek egyike, amikor adott feladat alapján gyűjtjük össze a szükséges egyedi jellemzőkkel, speciális kialakítással rendelkező eszközöket. Az elnevezések jól behatárolhatóvá teszik az eszköz fegyverzetét, vagy annak hiányát is (2. táblázat)

A kerekes harcjárművek a széleskörű alkalmazás mellett jelentős fejlesztésen mentek keresztül a vizsgált időszakban. Az okokat a felhalmozódó katonai tapasztalatokban, és az azokból következő fejlődő, bővülő katonai igényekben lehet keresni.

A cikksorozat ennek megfelelően a kerekes harcjárművek elmúlt évtizedbeli fejlesztéseire fókuszál. A szerzők tíz kerekes harcjárműcsaládot választottak ki, és ezen eszközök típusváltozatait mutatják be a járművek megjelenésének időrendi sorrendjében. A leírásokban szerepel:

- az eszközök tervezésének, gyártásának ideje, fontosabb körülményei;

- a járművek rövid bemutatása;

- a fontosabb fejlesztések és azok eredményei

- összefoglaló táblázat a technikai adatokról, a védettséget befolyásoló tulajdonságokról.

\section{A SZOVJeT/OROSZ BTR JÁrmÜvEK FEJLESZTÉSE}

A mai BTR típusok első példánya a BTR-60, amelyet 1960tól alkalmaztak először a Szovjetunióban, majd más államokban is. Az előd típusok a BTR-40 vagy a BTR-152, [22, 184. o.] még teherautó alvázra és hajtásláncra épített pán-
2. táblázat. A kerekes jármúvek elnevezései feledatkörök szerint [18, 680-931. o.], [19], [20], [21, 715. o.]

\begin{tabular}{|c|c|c|c|}
\hline $\begin{array}{l}\text { Rövi- } \\
\text { dítés }\end{array}$ & $\begin{array}{l}\text { Idegen } \\
\text { nyelvú } \\
\text { fogalom }\end{array}$ & $\begin{array}{l}\text { Magyar nyelvü } \\
\text { fogalom }\end{array}$ & $\begin{array}{c}\text { Példa a jármú, } \\
\text { vagy eszköz } \\
\text { típusra }\end{array}$ \\
\hline AFV & $\begin{array}{l}\text { Armoured } \\
\text { Fighting } \\
\text { Vehicle }\end{array}$ & $\begin{array}{l}\text { Páncélozott } \\
\text { harcjármű }\end{array}$ & FNSS Pars \\
\hline APC & $\begin{array}{l}\text { Armored } \\
\text { Personnel } \\
\text { Carrier } \\
\end{array}$ & $\begin{array}{l}\text { Páncélozott } \\
\text { (csapat) } \\
\text { szállítójármű }\end{array}$ & $\begin{array}{l}\text { Stryker M1126, } \\
\text { stb. }\end{array}$ \\
\hline ASV & $\begin{array}{l}\text { Armoured } \\
\text { Security } \\
\text { Vehicle }\end{array}$ & $\begin{array}{l}\text { Páncélozott } \\
\text { biztosító jármű }\end{array}$ & M1117 \\
\hline $\mathrm{CP}$ & $\begin{array}{l}\text { Command } \\
\text { Post } \\
\end{array}$ & Vezetési pont & Boxer \\
\hline CV & $\begin{array}{l}\text { Command } \\
\text { Vehicle }\end{array}$ & $\begin{array}{l}\text { Parancsnoki } \\
\text { jármű }\end{array}$ & Stryker M1130 \\
\hline ICV & $\begin{array}{l}\text { Infantry } \\
\text { Combat } \\
\text { Vehicle }\end{array}$ & $\begin{array}{l}\text { Gyalogsági } \\
\text { harcjármű }\end{array}$ & VAB mk III \\
\hline IFV & $\begin{array}{l}\text { Infantry } \\
\text { Fighting } \\
\text { Vehicle }\end{array}$ & $\begin{array}{l}\text { Gyalogsági } \\
\text { harcjármü }\end{array}$ & BTR-80A \\
\hline MEV & $\begin{array}{l}\text { Medical } \\
\text { Evacuation } \\
\text { Vehicle }\end{array}$ & $\begin{array}{l}\text { Sebesült kihordó } \\
\text { jármű }\end{array}$ & BTRSKJ \\
\hline MGS & $\begin{array}{l}\text { Mobile Gun } \\
\text { System }\end{array}$ & $\begin{array}{l}\text { Hordozható } \\
\text { fegyver- } \\
\text { rendszer }\end{array}$ & Stryker M1128 \\
\hline MPC & $\begin{array}{l}\text { Marine } \\
\text { Personnel- } \\
\text { Carrier }\end{array}$ & $\begin{array}{l}\text { Tengerész } \\
\text { csapatszállító }\end{array}$ & csak project \\
\hline RV & $\begin{array}{l}\text { Repair } \\
\text { Vehicle } \\
\end{array}$ & Javító jármű & VAB ELI \\
\hline TAPV & \begin{tabular}{|l|} 
Tactical \\
Armored \\
Patrol Vehicle \\
\end{tabular} & $\begin{array}{l}\text { Műveleti } \\
\text { páncélozott járőr }\end{array}$ & M1117 \\
\hline
\end{tabular}

célozott felépítmények voltak. Az új BTR-60 típusú harcjármű teljesen új konstrukció volt. $A$ járművek hajtását tekintve csak a tüzelőanyag maradt azonos, a BTR-152 típust egy Zil 132 benzinüzemű 6-hengeres motor a BTR-60 harcjárművet már két GAZ 49B szintén benzinüzemű 6-hengeres motor hajtotta, amelyek összteljesítménye 100 helyett $2 \times 66 \mathrm{~kW}$ (180 LE) volt. A BTR-60 típusnál jelent meg először alapfelszereltségként a központi kerékfúvató rendszer (CTIS - central tire inflation system), amely lehetővé tette a harcjármü-vezető számára az abroncsnyomás szabályzását, illetve a kis mértékben sérült abroncsok nyomásvesztésének kompenzálását. Ez a tulajdonság a harcjármű mozgásképességének megtartásában tölt be fontos szerepet. Hasonló megoldás már a BTR-152V1 típuson megjelent külső levegő-bevezetéssel, de sérülékenysége miatt az abroncsok kerékagyon keresztüli légellátást a BTR-152V2 típusnál is kidolgozták. Ez a típus azonban - bár 1959-ben került átdolgozásra - valójában a BTR-60-as megjelenése után, 1962-ben állt szolgálatba [23, 337-338. o.]. A BTR-60P, majd BTR-60PA, és az azt 


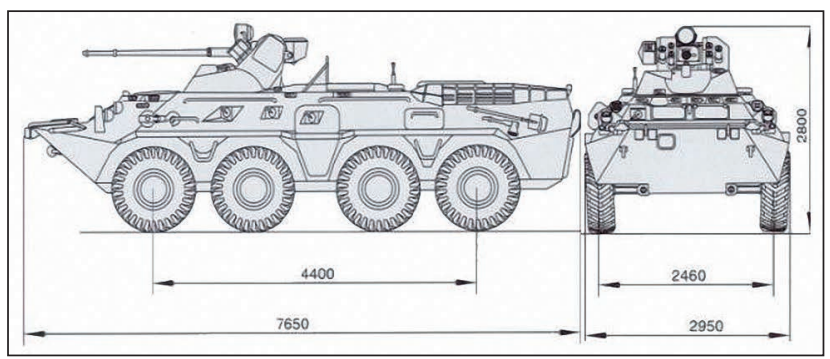

3. ábra. A BTR-80A páncélozott harcjármú méretei [25]

követő BTR-60PB változatok megjelenése között 3-3 év telt el [21 o. 884]. A $P$ változat tetejét még nem, de PA verzió tetejét már páncélozták, a $\mathrm{PB}$ modellre pedig a KPVT nehézgéppuskát is magába foglaló tornyot szereltek. A BTR-60 típust a BTR-70 követte, amelynél a legnagyobb külső változást az jelentette, hogy megjelentek a búvónyílások a jármű mindkét oldalán, az övvonal alatt. A BTR-60-as modernizált verzióin már előfordulhatott oldalsó búvónyílás a jármű övvolnala felett, az egyik oldalon.

A BTR-80 típust 1984-ben, a még rendszerben lévő BTR-60PB típusok kiváltására kezdték el kifejleszteni. A BTR-60 és 70 típusokhoz képest a hátsó traktus változott, illetve a két benzinmotor helyett egy Kamaz típusú 191 kW (260 LE) teljesítményű V8 elrendezésű feltöltött dízelmotort szereltek be. A BTR-80 és BTR-80A típus feltehetően a legnagyobb példányszámban gyártott kerekes harcjármű a világon. Az Magyar Honvédség 1996-tól 1999ig mintegy 500 db BTR-80 és 80A típusú kerekes harcjárművet szerzett be Oroszországtól [24 o. 650].

A BTR-80 és a 80A körkörösen hegesztett homogén acélpáncéllal rendelkezik, amely vastagsága a front rész alsó felén $15 \mathrm{~mm}$, az oldalfelületen $8 \mathrm{~mm} .^{3}$ Akna, improvizált robbanó eszköz (IED - Improvised Explosive Device), vagy RPG elleni védelme nincs az eszköznek. ${ }^{4}$

$A$ jármű elhagyását oldalt kettő, a jármü tetején négy búvónyílás teszi lehetővé, de hátul nincs deszantajtó. $A z$ eszköz állományának védelmét ABV (atom-biológiai-vegyi) szűrőberendezés segíti, a küzdőtér hermetikusan zárható, túlnyomás alá helyezhető.

A járművek kezelőszemélyzete 2 fő, a deszant létszáma 7 , illetve 8 fő. A BTR-80 típusok futómű felfüggesztése független keresztlengőkaros, az első és a hátsó tengelyen futóművenként 2-2 lengéscsillapítóval rendelkezik. A fékszerkezet dob kialakítású, és blokkolásgátló rendszer (továbbiakban: $A B S$ ) még a modernizált változatokban sincs. A kerekek a BTR-80A típuson belső futógörgős runflat rendszerüek, illetve központi abroncsfúvató rendszer segítségével állítható az abroncsnyomás. Az abroncsok mérete a BTR-80-as esetén 13-18, a BTR-80A esetén $1150 \times$ 400-475. ${ }^{5}$ Az eszköz úszóképes, vízen $10 \mathrm{~km} / \mathrm{h}$-val képes haladni. Vízfelszínen a hajtást a jármű kerekei és egy vízsugárhatjómű adja.

A BTR-80 fő fegyvere a 14,5 mm űrméretű KPVT nehézgéppuska [25, 330-331. o.], a BTR-80A fö fegyvere a 30 $\mathrm{mm}$ űrméretű $2 \mathrm{~A} 72$ gépágyú. Mindkét változat rendelkezik párhuzamosított PKT géppuskával, és egyik sem stabilizált. Pontos tüzelés menet közben nem, csak úgynevezett rövid megállások alkalmával lehetséges. A járműben tartózkodó állomány az egyéni lőfegyvereket a jármű oldalán elhelyezett nyílások alkalmazásával kiegészítő tűzerőként alkalmazhatja, amely megoldás az ellenséges rohamozó gyalogság elleni védelemben eredményes.

A BTR-80A alapjaira 1995-ben 120 mm-es önjáró aknavetőt is készítettek 2S23 típusjelzéssel. A forrás szerint [21 o. 659] ennek a verziónak a páncélzata már a 7,62 mm AP

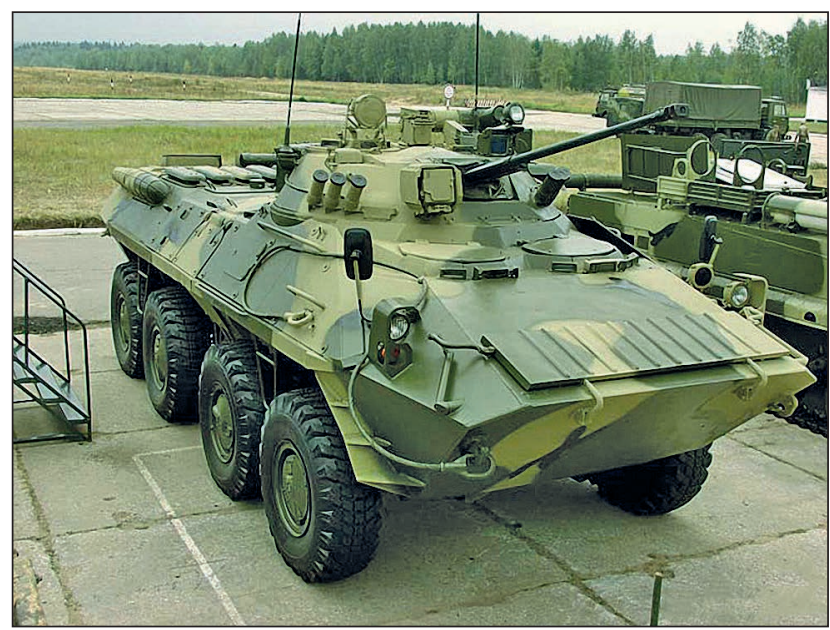

4. ábra. A BTR-90 kerekes harcjármü [28]

lőszer lövedéke ellen is védelmet nyújtott. A BTR-80-ra is szereltek reaktív pácélt, a Kontakt 5 rendszert a T-72-es harckocsiról szerelték át [24 o. 651].

A BTR-90-es harcjárművet 1993-tól kezdték kifejleszteni és 1994-ben mutatta be a GAZ (Gorkij Automobile Zavod). 2008-ig összesen 10 darab elkészült harcjárműről lehetett tudni, amelyeket az orosz védelmi minisztérium használt. Ez a harckocsi az előd modell legjelentősebb átalakítása.

A BTR-80 típushoz viszonyítva jelentős védelmi fejlődést jelentett, hogy a prototípus jármű elejének a ballisztikai védelme már 14,5 mm-es lövedékek ellen is védelmet nyújtott, de a jelenlegi információk [27, 582. o.], [21, 828-830. o.] alapján az eszköz védelmi képessége ennél is jobb.

A járművet körkörösen hegesztett homogén acél páncél védi, amelyre kiegészítő védőelem, vagy aktív védelmi rendszer szerelhető. A jármű padlólemeze lapos (tompaszögü) „,V” kialakítást kapott, szemben a BTR-80-as teljesen sima kialakításával, amelynek köszönhetően javult az akna elleni védelme. $A$ jármű elhagyását a tetőn lévő négy búvónyílás teszi lehetővé, hátsó deszantajtó ezen a típuson sincs.

$A$ jármű üres tömege (17t) és terhelhetősége $(5 t)$ is nőtt az előd modellhez képest. A BTR-90 hasmagassága 510 $\mathrm{mm}$, szemben a BTR-80 típus $475 \mathrm{~mm}$-es értékével. A mozgékonyságot, 375 kW (510 LE) teljesítményű dízelmotor és automata sebességváltó biztosítja, illetve az előd modellhez képest változás, hogy a vízen haladást két külső tolósugár teszi lehetővé.

A harcjármű a BTR-80A technikai alapjaira épült, de a BMP-2-es harcjármű fegyvertornyát kapta meg, amelybe beépítették a stabilizált 2 A72 30 mm-es gépágyút. A páncélelhárító eszközök számára rakétaindító állványokat is fel lehet szerelni, például AG-17-es, AG-30-as, Konkurs ATGW rakéták számára.

A torony átalakításával elkészítették a BTR-90M típust, amelyre egy 100 mm űrméretű ágyú mellett - párhuzamosítva - a $30 \mathrm{~mm}$ ürméretű gépágyút is felszerelték [28].

A BTR-90-es harcjármű magas gyártási költségei miatt, réskitöltő típusként tervezték meg a BTR-82 harcjárművet. A BTR-82-es első prototípusa 2009 decemberében gördült ki a gyárból, amely a BTR-80-as jóval kisebb mértékű áttervezésével jött létre. A harcjármű műszaki alapjai megegyeznek a BTR-80 típuséval. A BTR-82A típust napjainkban Oroszország és Kazahsztán alkalmazza.

A BTR-82A jármű ballisztikai védelmét növelik a laminált kevlár kiegészítő védőelemek. A jármű padlólemezét is jelentősen megerősítették és egy speciális gumipaplant is 
3. táblázat. A BTR típusok technikai adatai (védettség, méretek, szállítási kapacitás, mozgékonyság, tűzerō)

\begin{tabular}{|c|c|c|c|c|}
\hline & BTR-80 & BTR-80A & BTR-90 & BTR-82A \\
\hline tervezés kezdete & 1980 & 1980 & 1993 & nincs adat \\
\hline gyártás éve & 1984 & 1984 & 1994 & 2009 \\
\hline alap páncélzat anyaga & \multicolumn{4}{|c|}{ hengerelt homogén acélpáncél } \\
\hline alap páncélzat vastagsága $(\mathrm{mm})$ & $8-10$ & $8-10$ & nincs adat & $8-10$ \\
\hline minimális ballisztikai védelem $(\mathrm{mm})^{6}$ & 7,62 & 7,62 & 14,5 & 7,62 \\
\hline $\begin{array}{l}\text { kiegészítő védőelemekkel elérhető ballisztikai } \\
\text { védelem }(\mathrm{mm})^{7}\end{array}$ & - & - & 14,5 & 12,7 \\
\hline frontális ballisztikai védelem $(\mathrm{mm})$ & 7,62 & 7,62 & 30 & 12,7 \\
\hline akna elleni védettség (- / + / típus) & - & - & + & + \\
\hline IED elleni védettség (- / + / típus) & - & - & + & + \\
\hline repeszháló (- / + / típus) & - & - & + & + \\
\hline RPG elleni védelem (- / + / típus) & - & - & + & + \\
\hline vizuális álcázás / füstgránát (db) & 6 & 6 & 6 & 6 \\
\hline nem látható fénytartomány $(-/+)$ & - & - & - & - \\
\hline búvónyílások száma $(\mathrm{db})$ & 6 & 6 & 7 & 6 \\
\hline hátsó deszantajtó $(-/+)$ & - & - & - & - \\
\hline különálló függesztett ülések $(-/+)$ & - & - & - & - \\
\hline $\mathrm{ABV}(-/+)$ & + & + & + & + \\
\hline hosszúság (m) & 7,65 & 7,65 & 8,05 & 7,58 \\
\hline szélesség (m) & 2,9 & 2,95 & 3,06 & 2,985 \\
\hline magasság (m) & 2,35 & 2,8 & 3,05 & 2,915 \\
\hline kezelőszemélyzet (fő) & 2 & 2 & 3 & 2 \\
\hline deszant (fö) & 8 & 7 & 7 & 7 \\
\hline belső tér $\left(\mathrm{m}^{3}\right)$ & 6 & 6 & 7 & 6 \\
\hline terhelhetőség (t) & 0,8 & 1,35 & 5 & 1,5 \\
\hline motorteljesítmény (kW) & 191 & 191 & 375 & 220 \\
\hline maximális sebesség $(\mathrm{km} / \mathrm{h})$ & 80 & 80 & 100 & 80 \\
\hline üres tömeg (t) & 13,6 & 14,55 & 17 & 14,5 \\
\hline harci tömeg (t) & 14,4 & 16 & 22 & 16 \\
\hline mászóképesség (\%) & 30 & 30 & 60 & 60 \\
\hline oldaldőlés (\%) & 25 & 25 & 30 & 42 \\
\hline mellső terepszög $\left({ }^{\circ}\right)$ & 40 & 40 & 45 & 40 \\
\hline hátsó terepszög $\left(^{\circ}\right)$ & 30 & 30 & 30 & 30 \\
\hline kerékképlet & $8 \times 8$ & $8 \times 8$ & $8 \times 8$ & $8 \times 8$ \\
\hline árokáthidaló képesség (m) & 2 & 2 & 2,1 & 2 \\
\hline lépcsőmászó képesség (m) & 0,5 & 0,5 & 0,8 & 0,5 \\
\hline hasmagasság $(\mathrm{m})$ & 0,475 & 0,475 & 0,51 & 0,475 \\
\hline fordulókör-sugár (m) & 13,2 & 13,2 & 12 & 13,2 \\
\hline hatótávolság müúton $(\mathrm{km})$ & 600 & 600 & 850 & 500 \\
\hline sebességváltó kapcsolási elve $(\mathrm{m} / \mathrm{a})^{\star \star}$ & $\mathrm{m}$ & $\mathrm{m}$ & $\mathrm{a}$ & $\mathrm{m}$ \\
\hline sebességváltó fokozatok száma & $5+1$ & $5+1$ & na. & $5+1$ \\
\hline osztómű fokozatok száma & 2 & 2 & na. & 2 \\
\hline zárható differenciálművek & \multicolumn{4}{|c|}{ részleges önzárás } \\
\hline felfüggesztés típusa $(\mathrm{m} / \mathrm{f})^{\star \star \star}$ & $f$ & $f$ & $f$ & $f$ \\
\hline kerékméret & $13-18$ & $1150 \times 400-475$ & $14-20$ & $14-20$ \\
\hline defektmentes abroncs $(-/+)$ & + & + & + & + \\
\hline változtatható abroncsnyomás $(-/+)$ & + & + & + & + \\
\hline $\mathrm{ABS}(-/+)$ & - & - & - & - \\
\hline fékszerkezetek (tárcsafék/dobfék) & d & d & d & $d$ \\
\hline úszóképes (ú) / gázlómélység (m) & ú & ú & ú & ú \\
\hline fő fegyverzet űrmérete $(\mathrm{mm})$ & 14,5 & 30 & 30 & 30 \\
\hline lehetséges fegyverzetek ürmérete (mm) & 14,5 & 30 & 30 & 30 \\
\hline másodlagos fegyverzet $(-/ \mathrm{mm})$ & 7,62 & 7,62 & 7,62 & 7,62 \\
\hline stabilizált fegyver $(-/+)$ & - & - & + & + \\
\hline távirányított fegyver $(-/+)$ & - & - & - & - \\
\hline kiegészítő tűzerő (- / típus) & $7 \mathrm{gk}^{8}$ & $7 \mathrm{gk}$. & - & $7 \mathrm{gk}$. \\
\hline
\end{tabular}

* a [18, 777-788. o.], [21, 828-839. o.], [30], [28] alapján a szerző által készített táblázat.

** m: manuális/a: automata. $\quad{ }^{* * \star} \mathrm{m}$ : merev tengelyes; f: független.

$32 \rightarrow$ HADITECHNIKA LIII. évf. - 2019/6 


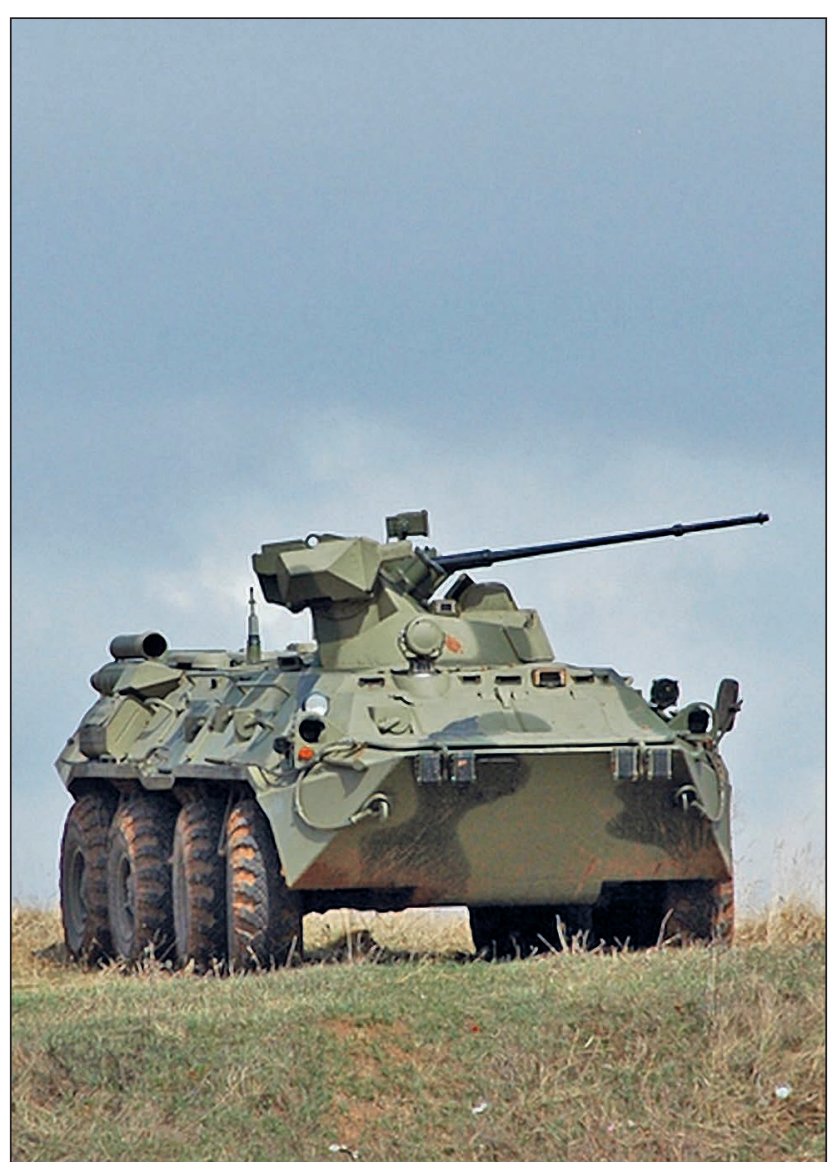

5. ábra. A BTR-82 harcjármű, a torony első felére kiegészítő ballisztikai védőelemet szereltek fel [29]

beszereltek az aknák elleni védelem érdekében [21, 831832. o.]. A gyártó szerint, aknára futás esetén ez $20 \%-k a l$ növeli a túlélés esélyét a küzdőtérben. Repeszhálót is alkalmaznak az eszköz küzdőterében, amely csökkenti a repeszkúpok szögét.

Fő fegyverzete a stabilizált 2A72 kettős adagolású 30 mm űrméretű gépágyú, amely a BTR-80A fegyverzeténél nagyobb szögben mozgatható, két különböző lőszer használatát és menet közbeni célra tartást tesz lehetővé.

A BTR típusok fejlesztése jól megfigyelhető:

- a ballisztikai védettség tekintetében a körkörös páncélozás után jelentős előrelépés nem volt, a korábbi típusok oldalpáncél vastagsága még $6,5 \mathrm{~mm}$ körüli érték volt, ezt a BTR-80 típusoknál már $8 \mathrm{~mm}$-re emelték;

- akna és IED elleni védelemmel csak a BTR-90 és BTR-82 típusok rendelkeznek, ezek a fejlesztések a '90-es évekre jellemző támadások miatt valósultak meg;

- mozgékonyság területén úttörőnek számított a BTR60 típus, a CTIS rendszerének, illetve az eszköz úszóképességének köszönhetően, a benzinüzemű motorokat turbófeltöltéses dízelmotor váltotta fel, amely teljesítményét a BTR-82 típus esetében megemelték;

- tűzerő tekintetében a 14,5 mm űrméretű nehézgéppuska után a $30 \mathrm{~mm}$ ürméretű gépágyút, majd stabilizált gépágyút szerelték be az eszközökbe.

A cikksorozat következő részében az osztrák, a német, illetve német-holland fejlesztésű kerekes harcjárműveket mutatjuk be.

(Folytatjuk)

\section{FELHASZNÁLT IRODALOM}

[1] „The Power Of 8 - Conclusions.” ThinkDefence.co.uk. Letöltve: 2018.05.12. https://www.thinkdefence.co. uk/2014/10/power-8-conclusions/;

[2] Nagy Norbert. „A beépített területen vívott harc során használt eszközök, alkalmazásuk sajátosságai." Seregszemle 8/1. (2010): pp. 29-45.;

[3] Michael Peck. „Army Boosts Production of Security Vehicle." National Defense, 89/2 Arlington, (2005): pp. 16-17. ProQuest military adatbázisból (Letöltés ideje: 2017.06.12.);

[4] Fleischer, Wolfgang. 1000 katonai jármü, Pécs: Alexandra kiadó, 2010.

[5] David B. „BTR-60.” Tank Encyclopedia 2014.11.22. Letöltve: 2019.07.15. http://www.tanks-encyclopedia. com/coldwar/USSR/soviet_BTR-60.php;

[6] Foss, Christopher F. (szerk.). Jane's Armour\&Artillery 2000-2001. Coulsdon: Jane'sInformation Group, 2000;

[7] Gávay György. „A Piranha Járművek fejlődése az alkalmazói igények tükrében." Hadmérnök 11/2 (2016): pp. 28-40. Letöltve: 2019.07.15. http:// hadmernok.hu/162_04_gavay.pdf;

[8] David B. „VAB.” Tank Encyclopedia. 2016.07.19. (Letöltve: 2019.07.15.) http://www.tanksencyclopedia.com/coldwar/France/VAB.php;

[9] http://www.hdcarwallpapers.in/wallpaper/m113armored-personnel-carrier-wallpaper-wallpapers.html Letöltve: 2019.08.30;

[10] Good, Bill. "Army's Stryker Double V-Hull is a resounding success," www.army.mil, Letöltve: 2019.09.12. https://www.army.mil/article/92154/ armys_stryker_double_v_hull_is_a_resounding_ success;

[11] Nagy Éva, Helfrih Viktor. A modern haditechnika enciklopédiája (1945-től napjainkig). Guliver kiadó, 2001.;

[12] Mike Sparks. „If M113s don'twork in snow, let'sfind out why." Armor 1997/02-03: 48-49.p;

[13] Bianchi, Fulvio; Bonsignore, Enzio; Wagner, Hans Joachim. „8x8: Winning Formula, or Technological Cul-de-Sac?" Military Technology 26/11, (2002): pp. 68-80.;

[14] Interim armored vehicle (IAV), Annualreport. globalsecurity.org Letöltve: 2017.06.12. https://www. globalsecurity.org/military/library/budget/fy2001/ dot-e/army/01iav.html;

[15] Foss, Christopher F. „Light Armoured Vehicles.” Jane'sDefenceWeekly 2003.02.19;

[16] Bera Bálint, Domokos Attila, Liszkai János, Molnár Zsolt. Modern Hadviselés. Debrecen: Szalai Könyvek, 2012.

[17] Lopocsi István. A Magyar Honvédségben rendszeresitett harcjármüvek harci lehetöségeinek elemzése és értékelése. Nemzetvédelmi Egyetemi Közlemények. Letöltve. 2019.07.15. http://193.224.76.2/downloads/ konyvtar/digitgy/20011/vszt/lopocsi.html;

[18] Christopher F. Foss (szerk.). IHS. Jane's Land Warfare Platforms - Armoured Fighting Vehicles 2014-2015. Coulsdon: IHS Global Limited, 2014

[19] Ocskay István. „A német-holland Boxer kerekes harcjármű - 2. rész." Haditechnika 51/4, (2017): pp. 13-20; https://doi.org/10.23713/HT.51.4.03;

[20] General Dynamics Land Systems. Letöltve: 2017.10.10. http://leanermoreagileabct.com/ products/stryker-and-specialty/stryker-CV.html;

[21] Foss, Christopher F. (szerk.). IHS. Jane's Land Warfare Platforms - Armoured Fighting Vehicles 2016 - 2017. Coulsdon: IHS Global Limited, 2016.; 
[22] Diószegi Imre, Döme Valéria, Gerlei István, Homér Zoltán, Kovács József, Major Balázs. „Védett katonai járművek a Gépjármű Beszerzési Programban - I. rész." Haditechnika 49/2, (2015): pp. 36-46.;

[23] Foss, Christopher F. (szerk.). Jane's Armour and Artillery 1992-93. Couldson: Janes' Information Group Limited, 1992.;

[24] Foss, Christopher F.: Jane's Land Warfare Platforms Armoured Fighting Vehicles 2012-2013. Coulsdon: IHS Global Limited, 2012.

[25] „BTR-80A Armoured vehicle personnel carrier."armyrecognition.com. Letöltve: 2019.07.15. https://www.armyrecognition.com/russia_russian_ army_wheeled_armoured_vehicle_uk/btr-80a armoured_vehicle_personnel_carrier_technical_data_ sheet_specifications_information_pictures.html;

[26] Foss, Christopher F. (szerk.). Jane's Armour and Artillery 1997-98. Couldson: Janes' Information Group Limited, 1997;

[27] Foss, Christopher F. (szerk.).Jane's Armour and Artillery 2009-2010. Couldson: IHS Jane's Global Limited, 2009;
[28] „BTR 90 - Armored personnel carrier.”military-today. com. Letöltve: 2019.0.7.15. http://www.military-today. com/apc/btr_90.htm;

[29] „BTR 82 - Armored personnel carrier.”military-today. com. Letöltve: 2019.07.15. http://www.military-today com/apc/btr_82.htm;

[30] „BTR80 tires” General Equipment Inc. Letöltés ideje: 2018.06.05. http://www.generalequipment.info/ BTR80\%20TIRES.htm.

\section{JEGYZETEK}

1 Fontos megjegyezni, hogy ez nem minden területen volt kivitelezhető, az amerikai haderő még napjainkban is alkalmazza az M113 típusú harcjárművet.

2 Például a Piranha járműcsalád változatai. [3]

3 Saját mérés eredménye (Gávay György).

4 Kísérleti jelleggel készült „bar armour” a járműhöz, amelyet a csecsen konfliktus alatt alkalmaztak.

$5 \mathrm{Az}$ abroncsok méretjelölésének módja eltérő, ennek oka nem ismert. 6 Az eszköz alap páncélzata által biztosan védett lőszer űrmérete és faitája. 12,7 mm-től mindegyik AP

7 Az eszköz alap páncélzata és a kiegészítő védőelemek által biztosan védett lőszer űrmérete és fajtája. $12,7 \mathrm{~mm}$ űrmérettől mindegyik AP. 8 A jármű személyzetének fegyverzete (gépkarabély).

\section{Chris McNab - Nyulászi Tamás (szerk.)}

\section{A legteljesebb túlélési útmutató}

A katonák túlélésre történő felkészítése az alapkiképzéssel kezdődik. Már ebben az időszakban is számos olyan hasznos ismeretet szereznek, amely váratlan helyzetekben életmentő lehet. A legteljesebb túlélési útmutató megtanít arra, hogyan kezeljük a válsághelyzeteket. A kötet szerkesztői a legszükségesebb önvédelmi fogásoktól a túlélőkészlet összeállításán keresztül, egészen a komoly krízishelyzetig vezetik az olvasót. (Megtudható például, hogy sivatagi körülmények között hogy lehet élelmet szerezni.) A túlélés minden esetben a felkészüléssel kezdődik. A szakkönyv elolvasása és az elképzelt, szimulált vészhelyzetből való szabadulás után nem nélkülözhető az alapvetó technikák, fogások természetben történő elsajátítása és begyakorlása.

A nemzetközi és a magyar különleges katonai erők módszereire alapozva, a könyv világos, lépésről lépésre elmagyarázott, rendkívül részletesen illusztrált útmutatót kínál a túléléshez. A kötet olyan túlélési helyzeteket mutat be, amelyek nyomán az olvasó megtudja többek között, hogy ha ismeretlen helyen eltéved, akkor hogyan tud magáról jelet adni, hogyan kell használnia a tájolót és a térképet, milyen módszerekkel tud élelemszerzés céljából csapdát készíteni, vagy milyen módszerrel tud vizet keresni. Az ismeretterjesztő összeállítás a katonákhoz és a civilekhez egyaránt szól, minden érdeklődő számá-

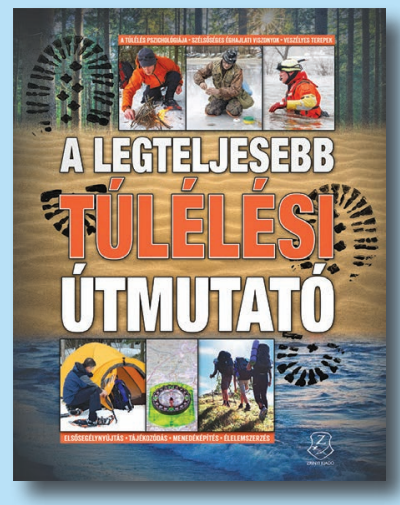
ra bemutatja az életben maradáshoz szükséges kulcsfontosságú technikákat.

Természeti és társadalmi katasztrófák a világ legfejlettebb régióiban is előfordulnak, ezért nem csupán a megelőzés, hanem - életveszély esetén - az életben maradás érdekében is előkészületeket kell tenni. Háztartási baleset bármikor bárkivel előfordulhat, ezek kezelésére, elhárítására a könyv teljes részletességgel nyújt tűzvédelmi és biztonsági tanácsokat. Önálló részek szólnak az elemi károk elleni védekezésről, az elsősegélynyújtásról, valamint az elsősegélycsomag tartalmáról, de az útmutató tanácsokat kínál az élelmiszer- és vízkészlet tárolással kapcsolatban is.

A kötet brit szerzője az Amerikai Egyesült Államok és az Egyesült Királyság elit katonai alakulatainak túlélési technikáit foglalta rendszerbe, ám a hazai kiadás a Magyar Honvédség speciális tapasztalataival kiegészítve jelent meg. A kötetet szójegyzék, tárgymutató és bőséges illusztrációs anyag egészíti ki.

A Zrínyi Kiadó által 2019-ben megjelentetett kötet puhatáblás, terjedelme 478 oldal. 6000 Ft-os áron kaptaható a könyvesboltokban, illetve a Zrínyi Kiadónál, 25\%-os helyszíni kedvezménnyel (1087 Budapest, Kerepesi út 29/b, Tel.: 06 1-459-5373, e-mail: gyoredina@armedia.hu), továbbá kedvezményesen megrendelhető a kiadó online felületén: http://www.hmzrinyi.hu/termek/a_legteljesebb_tulelesi_utmutato. (Walther Terézia) 